JOURNAL OF ARCHITECUTRE AND URBANISM RESEARCH

\title{
SUMATERA UTARA: PENGEMBANGAN POTENSI DAERAH DALAM DIKOTOMI SPASIAL DAN NON SPASIAL
}

\section{NORTH SUMATRA: DEVELOPMENT OF REGIONAL POTENTIAL IN SPATIAL AND NON-SPATIAL DICHOTOMIES}

\author{
* Erika Sari Br Ginting1)* \\ Magister Perencanaan Wilayah dan Kota, Fakultas Teknik, \\ Universitas Gadjah Mada, Indonesia
}

Diterima: Februari 2020; Disetujui: April 2020 ; Dipublikasi: 30 April 2020

*Corresponding author: E-mail : erika.ginting@gmail.com

\begin{abstract}
Abstrak
Sumatera Utara adalah provinsi dengan berbagai karakteristik, baik spasial dan non-spasial. Selama bertahun-tahun telah terjadi perdebatan tentang kesenjangan spasial yang besar dalam pembangunan yang ada di Sumatera Utara. Dalam tulisan ini, provinsi ini dibagi menjadi empat kelompok. Alokasi suatu kabupaten ke dalam suatu kelompok berdasarkan dua dikotomi. Pertama, dikotomi spasial antara kabupaten di dekat Danau Toba dan di luar wilayah danau. Kedua, dikotomi pembangunan ekonomi di antara wilayah Sumatera Utara. Metode untuk menentukan wilayah pertumbuhan tinggi atau rendah adalah Tipologi Klassen. Hasilnya adalah dua daerah di dekat Danau Toba adalah daerah pertumbuhan tinggi, namun lima di antaranya masih dinyatakan sebagai daerah pertumbuhan rendah. Sementara itu, untuk daerah di luar Danau Toba, enam di antaranya adalah daerah pertumbuhan tinggi dan delapan di antaranya masih di daerah pertumbuhan rendah. Dalam rangka meningkatkan pertumbuhan ekonomi setiap daerah, penting untuk mempromosikan dan mengembangkan strategi lokal.
\end{abstract}

Kata Kunci : wilayah pertumbuhan tinggi; wilayah pertumbuhan rendah; dikotomi spasial

\begin{abstract}
North Sumatera is a province with various characteristics, both spatial and non -spatial. For many years there has been a debate about the large spatial gaps in development exist in North Sumatera. In this paper, the province is divided into four groups. The allocation of a regency into a group based on two dichotomies. Firstly, the spatial dichotomy between the regencies near Lake Toba and outside the lake area. Secondly, the economic development dichotomy among the regions of North Sumatera. The method to determine high or low growth region was Typology Klassen. The result is two region near the Lake Toba are high growth regions, however five of them are still stated as low growth regions. Meanwhile, for the regions outside Lake Toba, six of them are high growth regions and eight of them are still in the low growth regions. In order to improve the economic growth of every region, it is important to promote and develop strategic local.
\end{abstract}

Keywords: high growth region; low growth region; spatial dichotomy

How to Cite : G. Erika Sari, (2020), Sumatera Utara : Pengembangan Potensial Daerah dalam Dikotonomi Spasial dan Non Spasial, J ournal of Architecture and Urbanism Research, 3 (2): Hal 139-153 


\section{PENDAHULUAN}

Pembangunan bertujuan untuk meningkatkan kesejahteraan masyarakat. Pembangunan daerah merupakan bagian integral dari pembangunan nasional, dan berlangsung secara berkesinambungan. Salah satu bidang yang penting adalah pembangunan bidang ekonomi.

Masyarakat di sekitar Danau Toba terkenal sebagai masyarakat yang menggantungkan hidupnya pada pertanian dan pariwisata. Sejak dulu, tanah di sekitar danau toba terkenal akan kesuburannya dan pemandangan danau yang indah banyak menarik wisatawan untuk berkunjung. Sayangnya kedua sektor ini tidak memberi dampak signifikan terhadap pertumbuhan ekonomi kabupaten di sekitar danau. Lima dari tujuh kabupaten di sekitar Danau Toba mengalami laju pertumbuhan ekonomi di bawah laju pertumbuhan rata - rata Provinsi Sumatera Utara.

Tujuan dari paper ini adalah untuk memberi gambaran dan rencana pengembangan wilayah di sekitar Danau Toba dan di luarnya, dengan membaginya menjadi dua dikotomi, yaitu wilayah berkembang cepat dan wilayah relatif tertinggal.

Menurut Supartoyo, pertumbuhan ekonomi mengukur prestasi dari perkembangan suatu perekonomian. Pengukuran akan kemajuan sebuah perekonomian memerlukan alat ukur yang tepat, berupa alat pengukur pertumbuhan ekonomi antara lain yaitu Produk Domestik Bruto (PDB) atau di tingkat regional disebut dengan Produk Domestik Regional Bruto (PDRB) yaitu jumlah barang atau jasa yang dihasilkan oleh suatu perekonomian dalam jangka waktu satu dan dinyatakan dalam harga pasar (Supartoyo, Tatuh, and Sendouw 2013). Boediono (1999) menyatakan bahwa pertumbuhan ekonomi merupakan proses kenaikan output per kapita dalam jangka panjang. Pertumbuhan ekonomi suatu negara dipengaruhi oleh akumulasi modal (investasi pada tanah, peralatan, prasarana, dan sarana dan sumber daya manusia), sumber daya alam, sumber daya munusia (human resources) baik jumlah maupun tingkat kualitas penduduknya, kemajuan teknologi, akses terhadap informasi, keinginan untuk melakukan inovasi dan mengembangkan diri serta budaya kerja (Muta'ali 2015).

Untuk mengetahui gambaran tentang pola dan struktur pertumbuhan ekonomi daerah dapat digunakan tipologi Klassen sebagai alat analisis. Analisis Tipologi Klassen pertama kali dikenalkan oleh Leo Klassen dari Netherlands Economics Institute. Tipologi Klassen ini adalah model yang paling popular untuk mengidentifikasi tingkat perkembangan perekonomian wilayah dengan menggunakan basis data besaran pendapatan per kapita dan pertumbuhan ekonomi dengan pembagian berdasarkan rata - rata. Dengan menggunakan alat analisis ini, dapat diperoleh empat klasifikasi pertumbuhan masing-masing daerah yaitu daerah pertumbuhan cepat (rapid 
growth region), daerah tertekan (retarded region), daerah sedang bertumbuh (growing region) dan daerah relatif tertinggal (relatifly backward region). Formulasi alat analisis ini adalah sebagai berikut:

Tabel 1 Klasifikasi Pertumbuhan Ekonomi Menurut Tipologi Klassen

\begin{tabular}{|c|c|c|}
\hline \multirow{2}{*}{$\begin{array}{l}\text { Laju } \\
\text { pertumb } \\
\text { uhan (r) }\end{array}$} & \multicolumn{2}{|c|}{ PDRB Per kapita (y) } \\
\hline & $y i>y$ & yi $<y$ \\
\hline $\mathrm{ri}>\mathrm{r}$ & $\begin{array}{l}\text { Wilayah } \\
\text { cepat } \\
\text { maju dan } \\
\text { cepat } \\
\text { tumbuh } \\
\text { (high } \\
\text { growth } \\
\text { and high } \\
\text { income) }\end{array}$ & $\begin{array}{l}\text { Wilayah } \\
\text { berkembang } \\
\text { cepat (high } \\
\text { growth but low } \\
\text { income) }\end{array}$ \\
\hline $\mathrm{ri}<\mathrm{r}$ & $\begin{array}{l}\text { Wilayah } \\
\text { maju tapi } \\
\text { tertekan } \\
\text { (low } \\
\text { growth } \\
\text { but high } \\
\text { income) }\end{array}$ & $\begin{array}{l}\text { Wilayah relatih } \\
\text { tertinggal (low } \\
\text { growth and low } \\
\text { income) }\end{array}$ \\
\hline
\end{tabular}

Sumber : (Muta'ali 2015)

Menurut Tipologi Klassen, wilayah dibagi menjadi empat klasifikasi, yaitu :

1. Wilayah cepat maju dan cepat tumbuh (high growth and high income). Merupakan wilayah yang memiliki tingkat pertumbuhan ekonomi dan pendapatan perkapita yang lebih tinggi disbanding rata rata Kabupaten/Kota di Provinsi
2. Wilayah maju tapi tertekan (low growth but high income). Merupakan wilayah yang memiliki pendapatan perkapita lebih tinggi tetapi tingkat pertumbuhan ekonominya lebih rendah disbanding rata - rata Kabupaten/Kota di Provinsi

3. Wilayah berkembang cepat (high growth but low income). Merupakan wilayah yang memiliki tingkat pertumbuhan tinggi, tetapi tingkat pendapatan perkapita lebih rendah disbanding rata - rata Kabupaten/Kota di Provinsi

4. Wilayah relatih tertinggal (low growth and low income). Merupakan wilayah yang memiliki tingkat pertumbuhan ekonomi dan pendapatan perkapita yang lebih rendah dibanding rata - rata Kabupaten / Kota di Provinsi.

\section{METODE PENELITIAN}

Dalam pembahasan perumahan dan permukiman ini digunakan metoda deskriptif dan komparatif. Ruang lingkup penelitian ini adalah 25 Kabupaten - kabupaten yang berada di Provinsi Sumatera Utara. Adapun kotamadya yang berada pada provinsi ini, tidak dimasukkan sebagai subjek penelitian ini.

Kabupaten yang diteliti pada kuadran adalah kabupaten yang masuk ke dalam kategori berkembang cepat dan relatif tertinggal, sedangkan wilayah cepat maju cepat tumbuh dan wilayah maju dan tertekan tidak disertakan dalam kuadran penelitian. 
Pada penelitian ini, Kabupaten kabupaten di Provinsi Sumatera Utara akan dibagi kedalam empat kuadran berdasarkan dua dikotomi secara spasial dan pertumbuhan ekonomi. Secara spasial, wilayah akan dibagi menjadi dua kelompok, yaitu wilayah di sekitar Danau Toba dan di luar kawasan Danau Toba. Sementara secara pertumbuhan ekonomi, kabupaten kabupaten tersebut akan dibagi menjadi dua, yaitu daerah tertinggal dan berkembang.

Untuk dikotomi non spasial, diambil wilayah berkembang cepat versus wilayah relatif teringgal dengan metode analisis Tipologi Klassen.

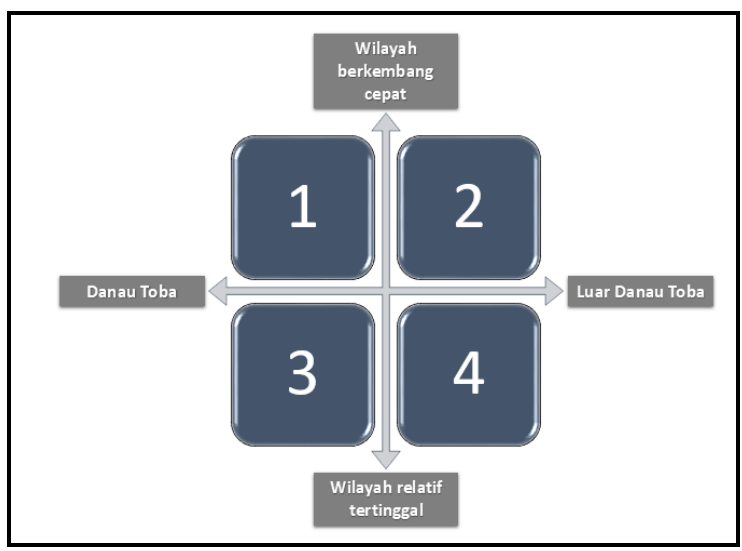

Gambar 1 Kuadran Kabupaten di Sumatera Utara Sumber : Analisa Penulis

Pembagian kuadran ruang berdasarkan dualisme spasial dan nonspasial menghasilkan 4 kuadran ruang sebagai berikut:
Tabel 2 Kuadran Sumatera

\begin{tabular}{llr}
\hline Utara & \\
\hline Kuadran & \multicolumn{2}{c}{ Keterangan } \\
\hline 1 & $\begin{array}{l}\text { Kabupaten } \\
\text { sekitar Danau Toba dengan } \\
\text { perekonomian } \\
\text { berkembang cepat }\end{array}$ \\
\hline 2 & $\begin{array}{l}\text { Kabupaten - kabupaten luar } \\
\text { Danau Toba dengan } \\
\text { perekenomian } \\
\text { berkembang cepat }\end{array}$ \\
\hline 3 & $\begin{array}{l}\text { Kabupaten - kabupaten } \\
\text { sekitar Danau Toba dengan } \\
\text { perekonomian yang relatif } \\
\text { tertinggal }\end{array}$ \\
\hline 4 & $\begin{array}{l}\text { Kabupaten - Kabupaten luar } \\
\text { Danau Toba } \\
\text { perekonomian yang relatif } \\
\text { tertinggal }\end{array}$
\end{tabular}

Sumber : Analisa penulis

\section{PEMBAHASAN}

Profil Wilayah Provinsi Sumatera Utara terdiri atas 33 Kabupaten dan Kota. Luas area 72.981,23 km2, terletak pada koordinat $0^{\circ}$ 50' LS - 4ㅇ 40' LU dan 96 $40^{\prime}$ - 100 50' BT. Dengan luas daratan 72.981,23 $\mathrm{Km}^{2}$, sebagian besar berada di daratan Pulau Sumatera dan sebagian kecil berada di Pulau Nias, Pulau - pulau Batu serta beberapa pulau kecil baik di bagian barat maupun bagian timur pantai Pulau Sumatera (BPS Provinsi Sumatera Utara 2016). 
Tabel 3 Batas Wilayah Sumatera Utara

\begin{tabular}{lll}
\hline Batas & Wilayah & \\
\hline Utara & Provinsi Aceh & \\
\hline Selatan & Provinsi Riau dan \\
& Sumatera Barat & \\
\hline Barat & Samudera & Indonesia \\
& Hindia & \\
\hline Timur & Selat Malaka & \\
\hline
\end{tabular}

Sumber : BPS Provinsi Sumatera Utara (2016)

Provinsi Sumatea Utara memiliki garis pantai sepanjang $1.300 \mathrm{Km}$. Panjang Garis Pantai Timur $545 \mathrm{Km}$, Panjang Garis Pantai Barat 375 Km dan Panjang Garis Pantai Pulau Nias 380 Km. Terdapat 419 pulau, dengan 237 pulau yang telah memiliki nama.

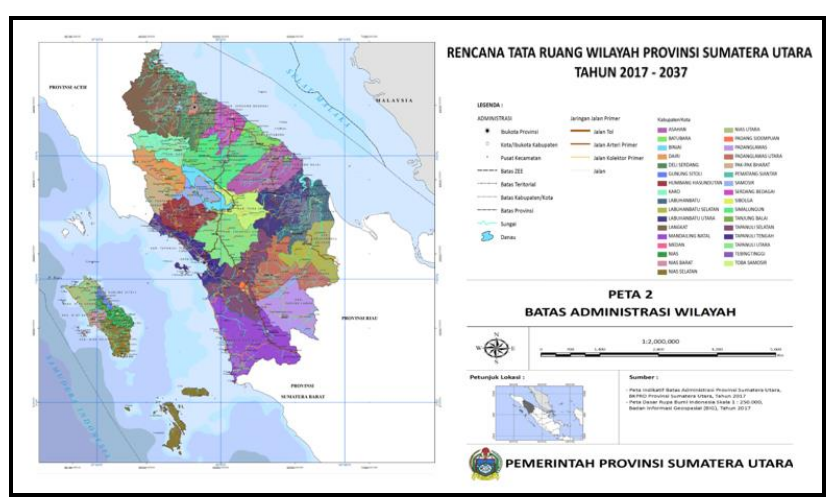

Gambar 2 Peta Administrasi Sumatera Utara

Sumber : Pemerintah Provinsi Sumatera Utara (2017)

Danau Toba adalah danau kaldera terbesar di dunia yang terletak di Provinsi Sumatera Utara, berjarak 176 km ke arah Barat Kota Medan. Danau Toba adalah danau terluas di Indonesia (90 x $30 \mathrm{~km} 2)$. Sebagai danau volcano tektonik terbesar di dunia, Danau Toba mempunyai ukuran panjang $87 \mathrm{~km}$ berarah Barat laut-Tenggara dengan lebar $27 \mathrm{~km}$ dengan ketinggian 904 meter dpl dan kedalaman danau yang terdalam 505 meter. Kondisi topografi Kawasan Danau Toba didominasi oleh perbukitan dan pegunungan, dengan kelerengan lapangan terdiri dari datar dengan kemiringan (0 - $8 \%$ ), landai (8 - $15 \%$ ), agak curam (15 - $25 \%$ ), curam (25 - $45 \%)$, sangat curam sampai dengan terjal ( $>45 \%$ ). (PUPR 2016)

Secara administratif, danau ini berada di tujuh Kabupaten di Sumatera Utara, yaitu Kabupaten Toba Samosir, Samosir, Humbang Hasundutan, Tapanuli Utara, Simalungun, Karo, dan Dairi.

\section{Kondisi}

Perekonomian,

Perhitungan Produk Domestik Regional Bruto Provinsi Sumatera Utara dilakukan dengan dua metode yaitu atas dasar harga berlaku dan atas dasar harga konstan (tahun dasar 2010).

PDRB ADHB Provinsi Sumatera Utara dalam kurun waktu tahun 20112015 menunjukkan tren pertumbuhan meningkat, yaitu sebesar Rp 377,037 Trilyun tahun 2011 meningkat menjadi sebesar Rp 571,722 Trilyun pada tahun 2015 sedangkan PDRB ADHK Provinsi Sumatera Utara dalam kurun waktu tahun 2011-2015 menunjukkan tren pertumbuhan meningkat, yaitu sebesar Rp 353,15 Trilyun tahun 2011 meningkat menjadi sebesar Rp 440,96 Trilyun pada tahun 2015 (Badan Pusat Statistik n.d.) 
PDRB per kapita Sumatera Utara untuk tahun 2014 - 2016 dapat dilihat pada table dibawah.

Tabel 4 Produk Domestik Regional Bruto Perkapita Provinsi Sumatera Utara Atas Dasar Harga Konstan 2010 (Juta rupiah) 2014 - 2016

\begin{tabular}{llll}
\hline Provinsi & 2014 & $\left.2015^{*}\right)$ & $\left.2016^{* *}\right)$ \\
\hline $\begin{array}{l}\text { Sumatera } \\
\text { Utara }\end{array}$ & 30,48 & 31,64 & 30,48 \\
\hline
\end{tabular}

Keterangan :

*) Angka Sementara

**) Angka Sangat Sementara

Sumber : BPS Provinsi Sumatera Utara (2016)

Laju Pertumbuhan Ekonomi, Berdasarkan data yang dirilis oleh Badan Pusat Statistik, laju pertumbuhan ekonomi Provinsi Sumatera Utara mengalami penurunan dari 5,23\& pada tahun 2014 menjadi $5,18 \%$ pada tahun 2016.

Tabel 5 Laju Pertumbuhan Ekonomi Provinsi Sumatera Utara Dasar Harga Konstan 2010 (persen) $2014-2016$

\begin{tabular}{llll} 
Provinsi & 2014 & $\left.2015^{*}\right)$ & $2016^{* *}$ ) \\
\hline $\begin{array}{l}\text { Sumatera } \\
\text { Utara }\end{array}$ & 5,23 & 5,1 & 5,18 \\
\hline
\end{tabular}

Keterangan $\quad:^{*}$ ) Angka Sementara $:{ }^{* *}$ ) Angka Sangat Sementara Pembagian Kuadran Secara spasial, wilayah Provinsi Sumatera Utara dibagi menjadi dua, yaitu wilayah
Danau Toba dan wilayah di luar Danau Toba.

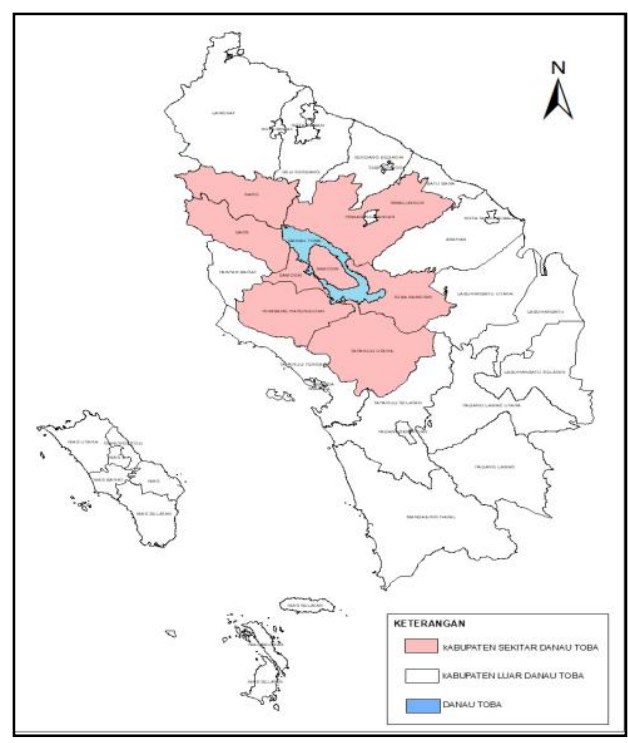

Gambar 3 Peta Kabupaten di sekitar Danau Toba SSumber : Analisa Penulis

Non Spasial, Dikotomi non spasial yang diteliti adalah wilayah berkembang cepat dan wilayah yang relatif tertinggal. Hal ini dilihat dari perkembangan ekonomi wilayah yang ditentukan dengan analisis Tipologi Klassen. Sehingga diperoleh data hasil analisis terhadap 25 Kabupaten di Sumatera Utara sebagai berikut :

Tabel 6 Analisis Tipologi Klassen di Sumatera Utara R Y

$$
\text { Yi }>\text { Y } \quad Y i<Y
$$

(1)

(2)

\begin{tabular}{lll}
\hline ri & Labuhanbatu & Mandailing \\
$>\mathrm{r}$ & Selatan & Natal \\
\cline { 2 - 3 } & Labuhanbatu & A s a h a n \\
& Utara & \\
\hline
\end{tabular}

Simalungun 


\begin{tabular}{ll}
\hline & Deli Serdang \\
\hline & Pakpak Bharat \\
\hline ri & Samosir \\
\hline Pabuhanbatu & Utara \\
\hline Batubara & Padang Lawas \\
\hline & Tapanuli \\
\hline Selatan \\
\hline Tapanuli \\
Tengah \\
\hline Tapanuli Utara \\
\hline Toba Samosir \\
\hline Dairi \\
\hline Karo \\
\hline Langkat \\
\hline Nias Selatan \\
\hline Humbang \\
\hline Hasundutan \\
\hline Serdang \\
Bedagai \\
\hline Nias Utara \\
\hline Nias Barat \\
\hline Penulis
\end{tabular}

Sumber : Analisa Penulis

Dari analisis tersebut, diambil kabupaten - kabupaten yang berada pada pada kolom dua (2), yaitu wilayah yang berkembang cepat dan wilayah yang relatif tertinggal.

Spasial dan Non Spasial, Dari penentuan kabupaten - kabupaten tersebut berdasarkan dikotomi yang telah ditentukan, maka diperoleh kuadran sebagai berikut:

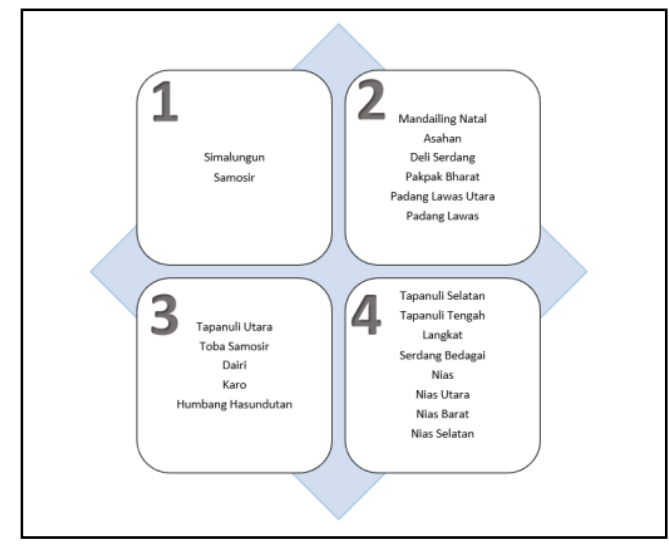

Gambar 4 Kuadran Spasial dan Non-spasial Sumber : Analisa Penulis

Dari kuadran di atas dapat dilihat bahwa hanya dua dari tujuh kabupaten Danau Toba yang merupakan wilayah berkembang cepat. Meskipun berkembang cepat, kedua wilayah ini masih memiliki PDRB per kapita yang lebih kecil dari PDRD per kapita Sumatera Utara.

Karakteristik Kuadran Pertama, Pada kuadran pertama, terdapat Kabupaten Simalungun dan Kabupaten Samosir. Kabupaten Samosir merupakan kabupaten yang relatif baru, yang merupakan hasil pemekaran Kabupaten Toba Samosir. Mengingat masih mudanya kabupaten ini, banyak potensi yang dapat dan masih terus digali oleh Pemerintah Daerah ini. Potensi utama kabupaten ini adalah pertanian, perkebunan kopi dan pariwisata. Pemerintah kabupaten sangat serius dalam mendorong perkembangan industri pariwisata dengan mengadakan festival wisata setiap tahunnya untuk mendorong meningkatnya kunjungan wisata.

Sementara Kabupaten

Simalungun, meskipun berada pada 
lokasi berdekatan dengan Danau Toba, kabupaten ini memiliki dualisme karakteristik. Bagian barat ke arah Danau Toba, merupakan dataran tinggi dengan topografi cenderung berbukit bukit sehingga cocok untuk pertanian. Sementara di bagian timur merupakan dataran rendah dengan topografi datar yang cocok untuk perkebunan kelapa sawit dan karet. Secara perekonomian, wilayah timur lebih makmur daripada wilayah di bagian barat. Perkebunan di Kabupaten Simalungun sudah cukup berkembang dan mapan. Perkebunan Teh, Karet dan Kelapa Sawit merupakan andalan daerah ini. Selain dikelola oleh PT Perkebunan Nusantara (PTPN), banyak perusahaan swasta maupun pribadi yang menanamkan investasi pada sektor ini. Di kawasan ini sedang dikembangkan Kawasan Ekonomi Khusus Sei Mangkei, yang merupakan kawasan industri terpadu seluas 7.000 Ha. Kawasan ini diharapkan dapat mengubah perekonomian Sumatera Utara yang mayoritas berbasis bahan mentah menjadi industri hilir. Selain potensi perkebunan dan industri di bagian timur, potensi pariwisata di bagian barat kabupaten ini juga cukup menjanjikan. Kota Parapat sudah menjadi tujuan wisata utama di Danau Toba sejak dahulu. Banyak investor yang membangun hotel dan akomodasi wisata lainnya di kota Parapat yang merupakan salah satu kota yang berada di pinggiran Danau Toba.

Masalah lingkungan hidup merupaka hal yang krusial pada kedua daerah ini. Berdasarkan evaluasi KLHK terkait kandungan baku mutu Danau Toba. Ditemukan bahwa total kandungan fosfor meningkat 300\% tahun 2012 (Arumingtyas n.d.). Hal ini disebabkan limbah deterjen dari usaha perhotelan dan rumah tangga. Selain itu, pakan ikan juga menyumbang andil besar dalam pencemaran air di Danau Toba.

Karakteristik Kuadran Kedua, Pada Kuadran kedua merupakan kabupaten di luar Danau Toba yang berkembang cepat. Secara administratif, kabupaten dalam kuadaran ini dapat dibagi menjadi dua kelompok, yaitu kelompok kabupaten hasil pemekaran (Mandailing Natal, Pakpak Bharat, Padang Lawas Utara dan Padang Lawas) dan kelompok kabupaten yang sudah berdiri sejak lama (Asahan dan Deli Serdang).

Pada kelompok pertama, sama seperti Kabupaten Samosir, masih banyak potensi pada kabupaten ini yang masih terus digali oleh pemerintah daerah sehingga kabupaten dapat terus berkembang. Potensi yang memberi kontribusi besar pada perekonomian kabupaten - kabupaten ini adalah perkebunan dan pertanian. Kabupaten Mandailing Natal, Padang Lawas dan Padang Lawas utara memiliki potensi besar pada perkebunan kelapa sawit, sementara Kabupaten Pakpak Bharat memiliki potensi besar pada pertanian dan hasil hutan non kayu seperti kemenyan dan nilam (kemendesa n.d.)

Pada kelompok kedua, yaitu Kabupaten Asahan dan Deli Serdang, merupakan Kabupaten yang sudah lama 
berdiri dan banyak menerima investasi, baik dari dalam maupun luar negeri. Potensi besar dari kedua kabupaten ini adalah perkebunan sawit dan industri pengolahannya. Banyak perusahaan besar dan ternama yang mendirikan perusahaan di wilayah kabupaten ini. Infrastruktur di kabupaten ini juga cukup memadai. Jalan raya yang merupakan jalan lintas timur sumatera melewati kabupaten Deli Serdang dan sedikit Kabupaten Asahan sehingga akses menuju pusat pemerintahan dapat terjangkau dengan cepat. Potensi lain dari Kabupaten Asahan adalah perikanan tangkap di pantai timur. Pada saat ini, banyak investor yang mengusahakan perikanan tangkap di wilayah perairan ini.

Karakteristik Kuadran Ketiga, adalah wilayah Danau Toba yang relatif tertinggal. Pada kuadran ini terdapat lima kabupaten yaitu Tapanuli Utara, Toba Samosir, Dairi, Karo dan Humbang Hasundutan. Perekonomian kelima kabupaten ini ditopang oleh sektor pertanian. Masyarakat mengandalkan lahan yang subur untuk pertanian, namun kurangnya sumber daya manusia menyebabkan sektor ini masih belum dapat memberi penghidupan yang lebih layak untuk masyarakatnya. Kurangnya investasi di kabupaten kabupaten ini juga menyebabkan sulit meningkatnya laju pertumbuhan ekonomi di daerah ini. Investasi yang terdapat di daerah ini lebih menekankan pada pemanfaatan sumberdaya hutan yang dikhawatirkan memicu terjadinya kerusakan lingkungan hidup di sekitar danau.

Untuk pariwisata, kelima kabupaten ini juga belum memaksimalkan keberadaan Danau Toba sebagai objek wisata. Meskipun pesona Danau Toba dari kelima kabupaten ini tidak kalah dengan Kabupaten Samosir dan Simalungun, namun lebih banyak investor memilih untuk berinvestasi pada kedua kabupaten tersebut dari pada lima kabupaten ini.

Karakteristik Kuadran Keempat, kabupaten - kabupaten yang masuk pada kuadran ini tersebar di pantai timur dan barat sumatera utara. Kabupaten Nias, Nias Utara, Nias Selatan dan Nias Barat merupakan kabupaten yang berada di sebelah barat di luar daratan Sumatera dan merupakan hasil pemekaran dari Kabupaten Nias. Kabupaten Mandailing Natal dan Tapanuli Selatan berada di pantai barat, sementara Langkat dan Serdang Bedagai berada di Pantai Timur pulau sumatera.

Kementerian Desa Pembangunan Daerah Tertinggal menetapkan Kabupaten Nias, Nias Utara, Nias Selatan dan Nias Barat sebagai daerah tertinggal (kemendesa n.d.). Kurangnya pasokan listrik dan kurang memadainya jalan menyebabkan daerah ini masih tertinggal dari kabupaten lain di Sumatera Utara.

Tapanuli Selatan dan dan Tapanuli Tengah merupakan daerah yang berada di pantai timur daratan sumatera. Kedua daerah ini sebenarnya 
memiliki potensi yang cukup memadai, akan tetapi kegiatan perekonomian lebih banyak terpusat pada Kota Padang Sidempuan dan Kota Sibolga yang sebelumnya merupakan ibukota kedua kabupaten ini yang kemudian memisahkan diri dari kabupaten kabupaten tersebut. Selain itu, kurang memadai nya jalan lintas barat sumatera yang melintasi daerah ini dapat menjadi penyebab tertinggalnya daerah ini. Perkebunan dan pertambangan merupakan sektor unggulan dari kedua daerah ini. Salah satu tambang emas yang cukup besar, beroperasi di Kecamatan Batang Toru, Kabupaten Tapanuli Selatan.

Kabupaten Langkat dan Suerdang Bedagai menerima investasi yang cukup besar di bidang perkebunan Kelapa Sawit. Selain itu, infrastruktur sudah cukup memadai di bagian timur dengan adanya Jalan Lintas Timur Sumatera. Akan tetapi di beberapa tempat, masih ditemukan kurang memadainya infrastruktur dan pengembangan potensi lokal.

\section{Konsep Pengembangan Kuadran}

Pertama, Pada kuadran ini terdapat rencana strategis yang perlu dikembangkan, yaitu : Pariwisata, Lingkungan Hidup, Pertanian dan Perikanan, Industri serta Perkebunan. Dengan ditetapkannya sebagai daerah strategis nasional dan kepariwisataan khusus, Danau Toba berpotensi menjadi salah satu daerah tujuan wisata berskala nasional bahkan internasional. Hal ini dilaksanakan dengan mengembangkan simpul - simpul kawasan pariwisata.

Simpul

Pariwisata

dikembangkan pada empat lokasi utama, yaitu Kecamatan Dolok Pardamean, Kota Parapat Kabupaten Simalungun, Kecamatan Simanindo dan Onan Runggu Kabupaten Samosir. Mesipun demikian, hampir semua kecamatan di Kabupaten Samosir memiliki potensi pariwisata yang perlu dikembangkan.

Pada tahap pertama, perlu dilakukan perbaikan infrastruktur seperti pelabuhan, jalan, listrik, energi, komunikasi, perumahan dan pemukiman. Tahap selanjutnya adalah pengembangan masyarakat sadar wisata di desa - desa tujuan wisata. Kemudian, perlu dikembangkan atraksi wisata yang menjadi unggulan di daerah ini yaitu wisata alam dan budaya.

Lingkungan hidup merupakan salah satu masalah krusial di Danau Toba. Untuk mencegah semakin besarnya pencemaran air di Danau Toba, maka perlu dilakukan konservasi sumber daya air danau dengan instalasi drainase pada wilayah sekitar Danau Toba. Untuk pencegahan, perlu dikembangkan sarana dan prasarana pemantauan kualitas air di sepanjang pantai Danau Toba. Selain itu, perlu dievaluasi usaha budidaya ikan secara massive oleh perusahaan berskala besar.

Kawasan agropolitan dikembangkan di Selatan dan Timur laut Kabupaten Simalungun. Untuk mengembangkan pertanian dan 
perikanan perlu diperkenalkan produk unggulan dari masing - masing daerah untuk selanjutnya dipromosikan pada simpul - simpul pemasaran. Kawasan Ekonomi Khusus Sei Mangkei perlu dipersiapkan untuk menjadi kawasan industri baru untuk penyerapan tenaga kerja. Potensi perkebunan yang perlu digali di kuadran ini adalah perkebunan kopi di kabupaten Samosir. Potensi perkebunan kopi terdapat di tiga kecamatan, yaitu Pangururan, Rongggur Nihuta dan Palipi. Hasil perkebunan ini nantinya akan dipasarkan pada simpul pemasaran di kota Pengururan.

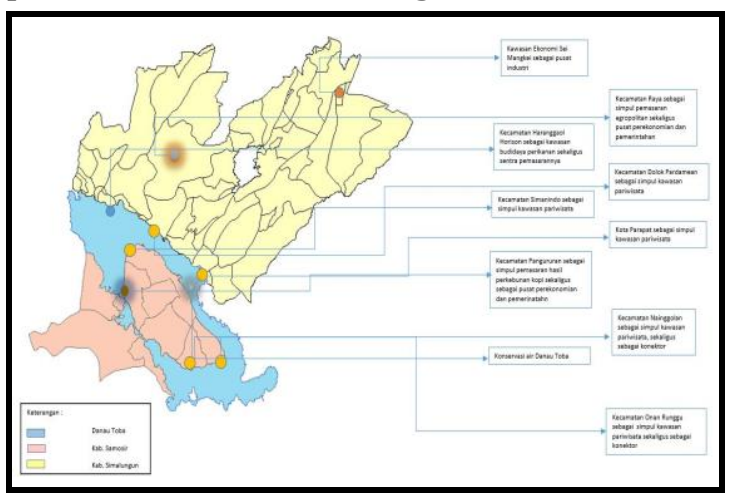

Gambar 5 Rencana Pengembangan Kuadran 1

Sumber : Analisa Penulis

\section{Konsep Pengembangan Kuadran}

Kedua, rencana strategis yang menjadi perhatian adalah pengembangan wilayah pemukiman, ekonomi, pengembangan perikanan tangkap, pengembangan pengolahan hasil hutan non kayu, kelapa sawit dan pengolahannya serta pengembangan infrastruktur.

Di kabupaten Deli Serdang dapat dikembangkan investasi di bidang perumahan dan pemukiman, mengingat banyaknya penduduk yang bekerja di
Kota Medan, tetapi memilih untuk tinggal dan membeli properti di Kabupaten Deli Serdang. Kabupaten ini juga menjadi gerbang masuk Provinsi Sumatera Utara dengan adanya bandara Internasional Kualanamu, maka perlu dikembangkan investasi di bidang perhotelan dan sarana pendukung lainnya.

Di Kabupaten Asahan, perlu dikembangkan perikanan tangkap dengan berbasis nelayan setempat agar masyarakat dapat menerima manfaat dari potensi perikanan di perairan ini.

Kabupaten Pakpak Bharat memiliki potensi hasil hutan kayu berupa nilam dan kemenyan. Untuk memberi nilai tambah pada komoditi ini, perlu dikembangkan industri pengolahan kedua komoditi ini di Kecamatan Salak yang merupakan ibukota kabupaten. Selain itu, pengembangan infrastruktur juga perlu diperhatikan di Kabupaten ini untuk mengatasi masalah konektivitas masyarakat dengan kabupaten lain atau ibukota provinsi.

Kabupaten Padang Lawas dan Padang Lawas Utara memiliki potensi yang mirip. Kedua kabupaten ini memliki potensi perkebunan kelapa sawit dan pengolahannya. Ibukota kabupaten keduanya dapat menjadi simpul pemasaran. Selain itu rencana pengembangan bandara di di Kecamatan Lubuk Barumun, Kabupaten Padang Lawas dapat mengatasi masalah konektivitas di kabupaten ini dan sekitarnya. 


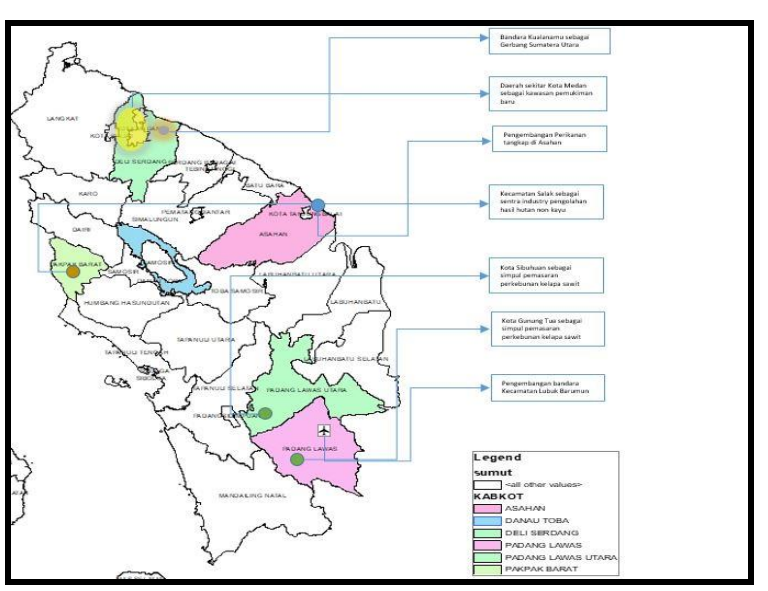

Gambar 6 Rencana Pengembangan

Kuadran dua

Sumber : Analisa Penulis

Konsep Pengembangan Kuadran Tiga, Pada kuadran ini pengembangan dititikberatkan pada revitalisasi infrastruktur dan pengembangan potensi lokal. Potensi yang perlu dikembangkan adalah Pariwisata, Pertanian dan Perkebunan.

Kabupaten Karo memiliki potensi besar di bidang pertanian, bahkan sudah dapat dikatakan maju. Kecamatan Mardinding perlu diberi perhatian untuk dikembangkan pertaniannya, selain itu Kecamatan Merek pernah dicanangkan sebagai sentra agropolitan, namun belum memberi hasil yang signifikan. Hampir semua kecamatan di kabupaten Karo sudah menunjukkan hasil yang cukup memuaskan dalam pertanian. Namun, yang kurang adalah sentra pengolahan hasil - hasil pertanian tersebut. Sehingga perlu dikembangkan sentra industri pengolahan hasil pertanian di Kecamatan Tigabinanga yang memiliki akses yang cukup baik ke pasar.
Untuk

pengembangan Pariwisata, kota Berastagi dikembangkan sebagai kota wisata, perlu diberikan kesempatan kepada investor untuk lebih mengembangkan pariwisata di daerah ini, selain itu kota ini juga menjadi sentra pemasaran hasil pertanian daerah sekitarnya. Kecamatan Merek juga perlu dikembangkan pariwisatanya dengan memperbaiki akses ke objek wisata di kecamatan tersebut.

Kabupaten Dairi memiliki potensi yang besar pada perkebunan kopi dan durian. Kedua produk ini cukup dikenal, akan tetapi masih belum memberikan dampak yang cukup signifikan bagi petani. Kedua potensi ini yang akan dikembangkan di Kota Sidikalang, sebagai ibukota kabupaten. Perlu dikembangkan sentra pemasaran hasil unggulan tersebut untuk memeberi manfaat yang maksimal bagi petaninya.

Pada bidang pariwisata, daerah ini juga memiliki potensi yang tidak kalah dengan Kabupaten Samosir. Desa Wisata Silalahi perlu dikembangkan dengan memperbaiki akses jalan raya, baik dari jalan lintas Medan - Sidikalang atau dari Tongging, yang selama bertahun - tahun masih mengalami kerusakan. Pengembangan Desa Wisata ini tidak hanya mengandalkan wisata alam saja, tetapi juga wisata budaya. Dengan adanya tugu Silahi Sabungan, dan festival budaya Pesta Tugu setiap tahunnya, dapat menarik lebih banyak wisatawan. 
Kabupaten

Humbang

Hasundutan memiliki potensi perkebunan kopi yang juga cukup terkenal. Kopi Lintong Nihuta cukup dikenal di Indonesia, bahkan ke luar negeri. Kota Doloksanggul dapat dikembangkan sebagai sentra pemasaran kopi ini.

Kabupaten ini juga dapat menarik investor di bidang energi. Kecamatan Tarabintang dan Parlilitan memiliki potensi yang besar sebagai Pembangkit Listrik Tenaga Mini Hidro (PLTMH).

Di bidang pariwisata, dapat dikembangkan wisata budaya di Kecamatan Bakti Raja yang merupakan istana Sisingamangaraja ke-12.

Kabupaten Tapanuli Utara memiliki potensi di bidang pertanian dan pariwisata. Kota Tarutung dapat menjadi sentra pemasaran pertanian dan juga sekaligus simpul pariwisata. Kecamatan Sipahutar dan sekitarnya perlu mengembangkan lagi pertanian Buah Nanas. Untuk bidang pariwisata, kecamatan Muara memiliki potensi yang cukup besar. Perlu dikembangkan transportasi melalui darat dan danau sehingga wisatawan dari Pulau Samosir dapat langsung menuju pulau kecil ini tanpa memakan waktu lama. Dengan diresmikannya bandara Silangit, maka akan lebih banyak wisatawan menuju pulau samosir, sehingga perlu dipersiapkan dermaga yang lebih layak. Selain itu juga perlu dilakukan konservasi air Danau Toba di sekitar dermaga agar potensi air tetap terjaga.
Kabupaten Toba Samosir memiliki potensi pertanian dan wisata. Pelabuhan Ajibata dapat dipersiapkan menjadi destinasi wisata yang lebih indah. Balige juga menjadi tujuan wisata budaya, selain itu juga kota ini menjadi sentra pemasaran hasil pertanian. Kecamatan Porsea, sebagai lokasi industri Pulp dari salah satu perusahaan yang cukup besar, perlu dikembangkan perekonomiannya dengan memanfaatkan Corporate Social Responsibility dari perusahaan tersebut.

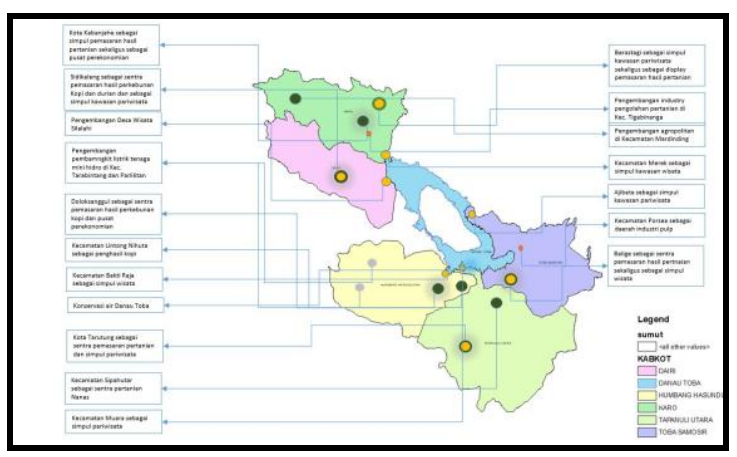

Gambar 7 Rencana Pengembangan

Kuadran tiga

Sumber : Analisa Penulis

Konsep Pengembangan Kuadran Empat, Sama seperti kuadran sebelumnya, pada kuadran ini dititikberatkan pada revitalisasi infrastruktur dan pengembangan potensi lokal.

Kabupaten - kabupaten di Pulau Nias perlu mengembangkan pariwisata pantai dan budaya. Pengembangan masyarakat sadar wisata perlu dilaksanakan di beberapa titik pengembangan wisata. Dengan potensi pantai yang cukup besar, dapat 
dilaksanakan festival - festival wisata dan olahraga surfing yang dapat menarik minat wisatawan lokal dan mancanegara.

Kabupaten Langkat memiliki potensi lokal di bidang ecotourism di sekitar Taman Nasional Gunung Leuser. Potensi ini dapat dikembangkan dengan tetap memperhatikan kelestarian lingkungan hidup. Hal ini perlu dilakukan mengingat banyak terjadinya konversi lahan hutan menjadi perkebunan kelapa sawit.

Seperti Kabupaten Langkat, Kabupaten Serdang Bedagai juga memiliki potensi besar di bidang pariwisata. Pantai Timur Kabupaten Serdang Bedagai perlu dikembangkan dan dipromosikan. Infrastruktur menuju pantai - pantai ini juga perlu diperbaiki.

Infrastruktur di Kabupaten Tapanuli tengah dan Tapanuli Selatan perlu diperbaiki. Jalan Lintas Barat Sumatera perlu direvitalisasi untuk mempermudah akses ke provinsi provinsi di bagian barat sumatera. Kabupaten Tapanuli Tengah juga perlu mengembangkan pariwisata pantai. Dengan potensi pantai yang indah dan keberadaan Pulau Mursala sebagai salah satu lokasi syuting Film Hollywood dapat dipromosikan lebih luas lagi. Selain pariwisata, di kabupaten ini juga dapat dikembangkan perikanan tangkap dengan berbasis masyarakat nelayan. Sehingga, meskipun pengusaha besar sudah banyak beroperasi dalam perikanan tangkap di perairan ini, masyarakat juga dapat menikmati hasilnya.

Kabupaten Tapanuli selatan perlu mengembangkan pemasaran hasil pertanian buah salak. Selain mengembangkan penjualan produk mentah, perlu juga dikembangkan industri hasil pengolahannya.

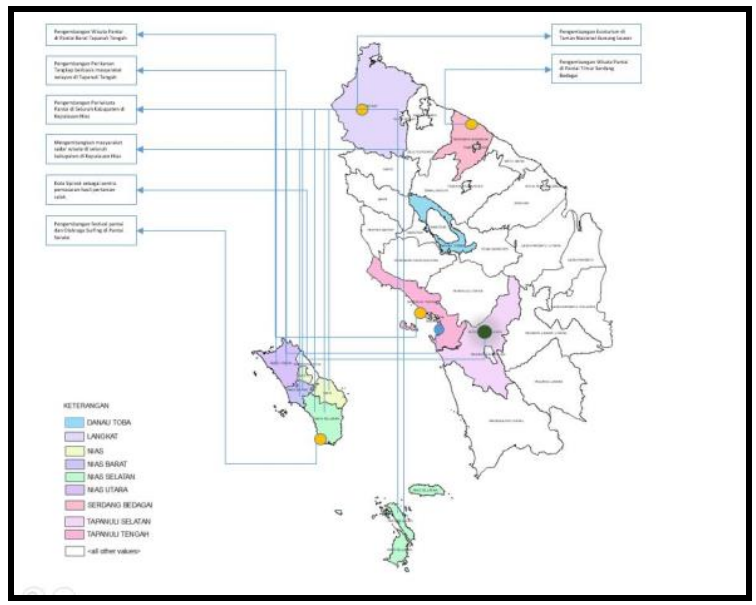

Gambar 8 Rencana Pengembangan

Kuadran empat

Sumber : Analisa Penulis

\section{SIMPULAN}

Dari analisis diatas dapat disimpulkan Sebagian besar kabupaten yang sekitar Danau Toba merupakan kabupaten yang relatif tertinggal, Kabupaten di timur sumatera relatif lebih berkembang dari pada di barat.

Perlu adanya simpul - simpul pengembangan untuk setiap kabupaten, Pengembangan potensi pariwisata perlu digarap secara serius untuk meningkatkan pertumbuhan ekonomi setiap kabupaten, engembangan infratruktur merupakan hal yang krusial untuk pengembangan potensi daerah, Perlu untuk mempertahankan kualitas 
lingkungan hidup untuk mendapatkan

manfaat yang berkelanjutan.

\section{DAFTAR PUSTAKA}

Arumingtyas, Lusia. n.d. "Makin Kritis, Restorasi Danau Toba Jadi Prioritas, Seperti Apa? - Mongabay.Co.Id." Accessed Juni 3, 2019; (Online) Tersedia : http://www.mongabay.co.id/2016/o6/20/ makin-kritis-restorasi-danau-toba-jadiprioritas-seperti-apa/ (Diakses 6 Juni 2019).

Badan Pusat Statistik. n.d. "Badan Pusat Statistik Provinsi Sumatera Utara." Accessed Juni 1, 2019 (Online) Tersedia https://sumut.bps.go.id/frontend/Subjek /view/id/52\#subjekViewTab3\%7Caccordi on-daftar-subjek2 (Diakses 6 Juni 2019)

Boediono, Teori Pertumbuhan Ekonomi, Yogyakarta, BPFE, 1999.

BPS Provinsi Sumatera Utara, Provinsi Sumatera Utara Dalam Angka 2016. Edited by BPS Provinsi Sumatera Utara. BPS Provinsi Sumatera Utara, 2016.

Kemendesa. n.d. "Provinsi Sumatera Utara | Kementrian Desa, Pembangunan Daerah, Juni 3, 2019 (Online) Tersedia

http://ditjenpdt.kemendesa.go.id/potensi/provi nce/25-provinsi-sumatera-utara (Diakses tggal 6 Juni 2019)

Muta'ali, Lutfi, Teknik Analisis Regional. Pertama. Yogyakarta: Badan Penerbit Fakultas Geografi Universitas Gadjah Mada, 2015.

Pemerintah Provinsi Sumatera Utara, Peraturan Daerah Provinsi Sumatera Utara Nomor 2 Tahun 2017 [Provincial Law of North Sumatera No 2 of 2017]." Medan, 2017.

PUPR, Kementaerian, Profil Kawasan Danau Toba, 2016.

Supartoyo, Yesi Hendriani, Jen Tatuh, and Recky H.E. Sendouw, "The Economic Growth and The Regional Characteristics: The Case of Indonesia." Buletin Ekonomi Moneter Dan Perbankan, pp 3-19, July 2013. 